\title{
STRUCTURING THE URBAN BUSINESS ENVIRONMENT PROBLEMS IN RETAIL BUSINESS RELOCATION AND BLACK ENTREPRENEURSHIP
}

\author{
Norman A. P. Govoni and George Joyce
}

Bowling Green State University

\section{Introduction}

The impact of public policy on the development and growth of urban areas in the United States has been one of substantial magnitude and the future promises even greater attempts to improve our urban environment. One of the major vehicles directed at urban redevelopment and improvement is the urban renewal program. Although the early urban renewal programs dealt primarily with residential housing, the concept of "community improvement" has become more important and increasing attention is being given to nonresidential forms of renewal. ${ }^{1}$ It has become apparent that no top-priority urgency is felt for purely housing goals for, in recent years, local planners have been shifting the emphasis in urban renewal away from housing needs toward an overall mix of needs, including commercial, industrial, and institutional. ${ }^{2}$

Under the community improvement concept of urban renewal, one of the most popular goals has been the revival of the downtown business a rea. Two major inseparable factors have contributed to the decay of many downtown commercial areas: first, a significant portion of the middle-income and upper-income consumers has moved its residency and transferred its store patronage to the suburbs, leaving in its place downtown mostly lowerincome consumers; and second, in addition to the loss of customers, downtown areas have become surrounded or even invaded by blight, which further reduces the competitiveness of the central city relative to the suburbs. These developments have placed a formidable task upon urban renewal programs to revitalize the urban complex.

Few would doubt that urban renewal programs are essential to the well-being of our cities. However, urban renewal projects, for all the good they do, tend to create additional problems which must be solved before the desired results of the total project can be fully realized. These satellite problems arise because urban renewal projects often severelydisrupt established social, economic and institutional relationships. Nowhere are these problems more graphically demonstrated than in the displacement and subsequent forced relocation of business--frequently small retail businesses. As one relocation expert said: "The forced movement of business units from established locations is certain to have disruptive consequences. 13

It is generally agreed that substantial strength of the American economic systems derives from the freedom of a businessman to make whatever decisions he pleases, when he pleases, in conducting his business. Urban renewal programs that require the relocation of a business interfere seriously with this decision-making freedom insofar as such programs require that decisions be made in the unfamiliar framework of a public program. The prospect of business relocation and the implementation of a business relocation plan can result in confusion, uncertainty, and resentment. But, these unsettling consequences can be minimized through properly conceived groundwork which is understood fully by all participants in the program; namely, the business itself, the local renewal agency, and the federal government. ${ }^{4}$ 
Although elaborate conscientious programs for family relocation have developed, business relocation programs have been characterized by narrow, restrictive assistance. It has been suggested that, in most instances, business relocation programs are minimal, "because the local planning a uthority is lulled into a sense of euphoria by the apparent and misleading selfsufficiency of business enterprises. 15

\section{$\underline{\text { Problems in Business }} \underline{\text { Relocation }}$}

In the course of assisting businesses with relocation, many different types of problems are encountered. Most are specific in nature and relate to the unique characteristics and requirements associated with individual firms. Some problems, however, are of a more general nature and seem to pervade the over-all framework of business relocation. These major problems relate to: (a) the ceiling placed on relocation payments; (b) small, marginal firms; (c) the shortage of time for relocating; (d) the shrinking supply of suitable space and rising rent levels due to competition from other displacees; (e) the fact that timing of the move is in the hands of "others"; (f) the frequent impossibility of developing an internal financial position sound enough to qualify for loans; and $(\mathrm{g})$ the restrictions of zoning regulations. 6

Although detailed discussion of each of the aforementioned problems is beyond the scope of this paper, elaboration upon one problem area will illustrate the bewildering predicament sometimes caused by urban renewal. For example, because timing of the relocation is in the hands of "others," the entrepreneur often suffers economic hardship in the period between the announcement and the actual start of an urban renewal project. Two aspects of timing are pertinent: the amount of time for the relocation and the control factor which rests with governmental agencies. Frequently, the announcement creates a "wet blanket" effect which depresses the entire area. The area's attractiveness is reduced as tenants are anxious to move out. Businessmen who remain in the area incur loss of income as renewal demolition and construction take place. Further loss of income occurs during the actual period of packing, moving, and resettling at a new location. Finally, at least six months is required for effective adjustment to the new location; however, periods up to two years may be necessary for complete adjustment.

The inherent problems of relocation are furthe $r$ increased by factors such as the lack of managerial skills, lack of sufficient formal training and lack of planning that seem to characterize many inner city entrepreneurs. Indeed, a combination of environmental and entrepreneurial conditions makes a business relocation program a complex undertaking.

The concern of the ghetto and, subsequently, minority enterprise can be viewed from these two broad perspectives: environmental, including consumer characteristics, and entrepreneurial. Both are studied from the standpoint of achieving an improved environment which will reduce if not resolve the social problem of urban crisis. ${ }^{7}$

Essentially, the environmental aspects are concerned with the revitalization and modernization of the inner city. The basic objective of minority enterprise is for improvement of minority members by providing an opportunity to share in the general economic system. ${ }^{8}$

\section{Environmental Conditions}

Because factors such as high crime rates boost operating costs and riots prevent the acquisition of needed insurance, ghetto merchants tend to 
operate marginally with low quality goods, inefficient management and poor profits typifying their operations. As a consequence, the ghetto dweller pays more for his goods and little is added to the environment in the form of jobs or income. 9

Infact, ghettos suffer from a deficit balance of payments. This unfavorable conditionis a result of ghetto residents' inability to produce surplus which is demanded outside the area. Therefore, these residents are total consumers. The Negro community as a collective has an estimated income of $\$ 32$ billion dollars annually. If ranked according to annual income compared to other nations, the ghettos of this country would be tenth in the world. 10

There are those who feel that it is possible and practical to implement programs that will bring new life to these areas. Mr. Leonard Evans concludes that:

The ghetto, in its present form, is an economic ghost town, thrashing in a death agony; yet paradoxically, it holds the greatest concentration of consumer purchasing power per squaremile in the United States, and possibly the world. 11

One sector of the ghetto community which has attracted both economic interest and political favor has been minority enterprise due to the direct dependency of business operation on consumer demand for goods and services.

\section{Consumer Characteristics}

It may be meaningful to view the low income consumer as a block dweller who sees himself as part of a "neighborhood," not as partof a city. Wall characterized him in the following manner:

His peer relationships are close in this limited environment, and as a consumer, he is strongly motivated to shop within these confines The poor consumer is less psychologically mobile, less active, and more inhibited in his behavior than well-to-do customers. The stores he considers for possible purchases are always small. The poor people more often buy at the same store. A comparison of shopping habits of middle class and working class women shows fewer lower class regularly shop in the central business district. 12

Additional insights about the "neighborhood" orientation may be drawn from a model of the commercial structure developed by Professor William Cox. ${ }^{13}$ The objective of Cox's model is to serve as a basis for assistance in solving urban problems of the inner city.

\section{Entrepreneurial - Retail Structure}

When classified by type of business, black entrepreneurship in this country can be best categorized as retailing. Therefore, attention is centered on the retail structure in the inner city.

It should be well understood that urban renewal programs, in the effort to achieve objectives, require significant changes in the community and its people. One of the important adjustments relates to the structure of the retail business environment of the affected community. Past business structures no longer are meaningful under the new conditions. The refore, a new business structure is necessitated to adequately provide the desired pro- 
ducts and services.

The number of small businesses in central cities has been declining. Studies suggest that the inner city areas are characterized by a high degree of instability of small retail businesses as reflected in failures and rates of turnover. 14

Brian Berry in an urban study undertaken in the 1960 's pointed out that:

... since race of owner is usually correlated with a va riety of other variables such as level of education, skills, capital resources, general business know-how, site preference, type of business as a profit-making enterprise or as a way of life, and since Negroes make up the largest percentage of persons in the low-income levels, Negroowned business in Negro communities undergoing urban renewal generally have high liquidation rates. ${ }^{15}$

It has been indicated that the major causes of retail failures a re poor management and lack of capital. Another obstacle facing the black entrepreneur is the position of low esteem he holds in the Negro community. Too often the frustrations and hopelessness of the ghetto dwellers are directed toward the Negro businessmen and generally parents do not encourage their children to pursue business careers for this reason. ${ }^{16}$ The Negro is probably more under-represented in business activity than in any other occupational pursuit. It has been estimated that more than 11 per cent of the white population work as "managers, officials and proprietors"'; while the figure for non-whites is less than 3 per cent. 17

The limitations of the black entrepreneurs coupled with the environmental restrictions suggest that an unusual effort must be made if the inner city retail business is to be able to adequately serve its market component.

When economic vitality is pumped into the ghetto community by self-determination, by new investment, and by new, sophisticated economic and financial creativity, there will be a restructuring in the patterns of distribution, e.g. , in the number of supermarkets per square mile, per thousand consumers, etc. There will be shifts and changes in management and ownership of wholesale distributing facilities. There will be greater participation of black people in controlling the economics of their community. 18

\section{In Conclusion}

In view of the previously cited conditions concerning the ghetto environment, the black entrepreneur and the low-income consumer, it does not seem appropriate to depend on the market mechanism to solve the inner city crisis.

Because of the existent conditions and the fact that these problems have been brought to the attention of the public, numerous programs have been implemented, the majority being initiated and sponsored by various federal agencies.

Underlying these efforts is the main objective of transforming a condition of urban blight to one of economic and social acceptance with productive potential and community service capabilities. 
It has been mentioned that one of the most important of these federal programs is that of urban renewal. According to Professors Brunner and Klein:

Urban renewal facilitates the assembly of disparately owned parcels of land, demolition or renovation of buildings, and resale of cleared or rehabilitated property at a cost of reflecting expected use. Thus the development of modern facilities for merchandising, distribution, or manufacturing in the urban core is made possible and economically attractive. 19

All small business is undergoing challenge ahd change. As a result of urban renewal, retailing establishments a re being concentrated into shopping centers and other types of business are being dispersed to the urban perimeter.

According to recent estimates, 60, 000 businesses had been displaced by urban renewal by 1966 and forecasts show 100, 000 to 120,000 businesses will be displaced by 1972.20

It is apparent then that implemented urban renewal projects result in new retail structures; the benefits of which are yet to be determined from experience.

In the short run, urban renewal is probably bad for all small businessmen in a renewal area. But over the long run, urban renewal may be beneficial to the remaining businessmen. If the government establishes black capitalismprograms, it could be in the position of conducting two major projects, one of which (urban renewal) works against the goals of the other (minority enterprise). 21

The inner city sector is a part of the urban area and, therefore, a weakness when measured in socio-economic performance. It must be studied and improved as market conditions or public policy dictate.

There is no formula which can assure a quick, easy, or inexpensive solution to the problems of urban renewal as they relate to the displacement and relocation of businesses. However, an attempt to understand the real impact of urban renewal programs on a community and its people, including the businessmen, will go far toward providing the insight necessary to intelligently and equitably surmount the obstacles.

Urban renewal program administrators must be alert to and have a knowledge of the fact that the entrepreneur faced with relocation seeks an understanding of his individual problems. The businessman's cooperation in the renewal program is related directly to the manner in which he is approached, the services available to him, and the program's flexibility designed to accomodate his unique needs. It is of critical importance that the local planning authority meet the affected businessmen in an atmosphere of mutual understanding and without any preconceptions.

Since the local planning authority's attitude toward relocation is immediately apparent to the businessman, the initial contact sets the tone for the entire duration of the relationship. Therefore, preparation by the local planning authority is paramount. Preparation is no simple task, as a relocation programmust have flexibility to adjust to a variety of circumstances. As one analyst suggested, the local planning authority must recognize: 
1. That the goal of materially reducing forced liquidations of businesses is achievable;

2. That business relocation is essentially a small business problem requiring, in addition to careful preparation on the part of the LPA, the active participation of other agencies, public and private, in the solution of problems;

3. That adequate time must be allowed for the business to plan and arrange its move;

4. That maximum use must be made of available financial assistance;

5. That "aging" businessmen pose extremely difficult relocation problems that a re more often related to personal matters than to business affairs. 23

Recognition by the local planning authority that rigid rules will not enable effective business relocation is prerequisite to a sound understanding of relocation problems and will aid in the implementation of a relocation program which achieves ha rmony on an individual basis.

Planners must be cognizant of the environmental characteristics and the entrepreneurial considerations which must be acknowledged and coordinated toward desiredobjectives. Recognition of the dynamics encompassed by political, social and economic influences is paramount to success on the part of affected businessmen. 


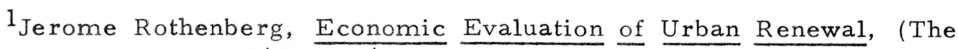
Brookings Institution, 1967), p. 69.

${ }^{2}$ Ibid.

${ }^{3}$ Basic G. Zimmer. Rebuilding Cities, (Quadrangle Books, 1964), p. 46.

$4_{\text {House Select Committee on Small Business, Problems in Urban }}$ Areas, June 21-July 14, 1966, p. 45.

${ }^{5}$ Ibid.

${ }^{6}$ Advisory Commission on Intergovernmental Relations, Relocation: Unequal Treatment of People and Businesses Displaced by Governments, 1965 , p. 55 .

${ }^{7}$ Bernard H. Booms and James E. Ward, Jr., "The Cons of Black Capitalism," Business Horizons, XII (October, 1969), p. 18-19.

${ }^{8}$ Ibid.

${ }^{9}$ Walter F. Mondale, "The Challenge of the Ghetto to Marketing," in A New Measure of Responsibility for Marketing, ed. by Cox and Enis, (American Marketing Association, 1968), p. 14.

${ }^{10}$ W. LeonardEvans, Jr., "Ghetto Marketing: What Now, " in Marketing and the New Science of Planning, ed. by Robert L. King, (American Marketing Association, 1968), p. 528.

${ }^{11}$ Ibid., p. 529.

12 Kelvin A. Wall, "Marketing to Low Income Neighborhoods: A Systems Approach," in Marketing in a Changing World, ed. by Bernard A. Morin, (American Marketing Association, June, 1969), p. 25.

13William E. Cox, Jr., "A Commercial Structure Model for Depressed Neighborhoods, "' Journal of Marketing, July, 1969, pp. 1-9.

${ }^{14}$ Brian Berry, et al, The Impact of Urban Renewal on Small Business, (University of Chicago, Center for Urban Studies), p. 116 .

${ }^{15}$ Brian Berry, Commercial Structure and Commercial Blight: Retail Patterns and Processes in the City of Chicago, (Research Paper No. 85, University of Chicago Department of Geography, 1963).

${ }^{16}$ Robert B. McKersie, "Vitalize Black Enterprise, " Harvard Business Review, September-October, 1968, p. 90.

${ }^{17}$ Dan Cordtz, "The Negro Middle Class is Right in the Middle, " Fortune, November, 1966, p. 174 .

18 Evans, op. cit., p. 529.

${ }^{19} \mathrm{G}$. Allen Brunner and Thomas A. Klein, "Marketing and Minority Enterprise: Opportunity or Syndrome, " in Marketing In A Changing World, (American Marketing Association, June, 1969), p. 29. 
20 Booms and Ward, op. cit., p. 22.

$21_{\text {Ibid., p. } 23 .}$

${ }^{22}$ House Select Committee on Small Business, op. cit., p. 47. 